\title{
Ancient DNA reveals kinship burial patterns of a pre-Columbian Andean community
}

\author{
Mateusz Baca ${ }^{1 *}$, Karolina Doan², Maciej Sobczyk' ${ }^{1}$ Anna Stankovic ${ }^{2,3}$ and Piotr Węgleński ${ }^{3,4}$
}

\begin{abstract}
Background: A detailed genetic study of the pre-Columbian population inhabiting the Tompullo 2 archaeological site (department Arequipa, Peru) was undertaken to resolve the kin relationships between individuals buried in six different chullpas. Kin relationships were an important factor shaping the social organization in the pre-Columbian Andean communities, centering on the ayllu, a group of relatives that shared a common land and responsibilities. The aim of this study was to evaluate whether this Andean model of a social organization had an influence on mortuary practices, in particular to determine whether chullpas served as family graves.

Results: The remains of forty-one individuals were analyzed with both uniparental (mtDNA, Y-chromosome) and biparental (autosomal microsatellites) markers. Reproducible HVRI sequences, autosomal and Y chromosomal STR profiles were obtained for 24, 16 and 11 individuals, respectively. Mitochondrial DNA diversity was comparable to that of ancient and contemporary Andean populations. The Tompullo 2 population exhibited the closest relationship with the modern population from the same region. A kinship analysis revealed complex pattern of relations within and between the graves. However mean relatedness coefficients regarding the pairs of individuals buried in the same grave were significantly higher than those regarding pairs buried in different graves. The $Y$ chromosome profiles of 11 males suggest that only members of one male line were buried in the same grave.

Conclusions: Genetic investigation of the population that inhabited Tompullo 2 site shows continuity between pre-Columbian and modern Native Amerindian populations inhabiting the Arequipa region. This suggests that no major demographic processes have influenced the mitochondrial DNA diversity of these populations during the past five hundred years. The kinship analysis involving uni- and biparental markers suggests that the community that inhabited the Tompullo 2 site was organized into extended family groups that were buried in different graves. This finding is in congruence with known models of social organization of Andean communities.
\end{abstract}

\section{Background}

Ancient DNA analysis of pre-Columbian individuals from South America has most often been conducted to determine the number and timing of initial migrations to the Americas [1] and to infer demographic changes in Amerindian populations [2-6]. In these studies mitochondrial DNA (mtDNA) was used because it is usually the only marker, available for use with ancient DNA samples. More recently nuclear markers, such as microsatellites, have been successfully applied to ancient material, making detailed analysis of kinship between individuals possible [7,8].

\footnotetext{
* Correspondence: bacamat@gmail.com

${ }^{1}$ Center for Precolumbian Studies, University of Warsaw, Krakowskie Przedmieście 26/28, 00-927, Warsaw, Poland

Full list of author information is available at the end of the article
}

Kin relations play an important role in pre-Columbian Andean cultures [9]. The basic sociopolitical unit of Native South Americans, the ayllu, was based on true or supposed kin relations [10-12]. The word ayllu could also refer to a group of kin relatives. The origins of ayllu-based communities are connected with the appearance of chullpas (i.e. above ground mortuary monuments) [11], which appeared in the archaeological record during the Early Intermediate Period in the northern highlands of modern Peru, and spread across the whole Central Andes, to become the predominant form of mortuary buildings in the Late Intermediate Period [11]. Apart from their funerary and religious functions, chullpa became an important element in the sociopolitical organization of Indian communities as places of collective reference, where ancestors were buried. Ancestor worship, widespread in pre-Columbian cultures

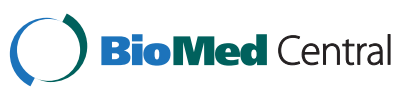


$[11,13]$, relied upon the veneration of ancestors, as shown by their presentation in public places, simulating their participation in everyday life. Thus a belief about origin from the same common ancestor was the basis for belonging to a particular group $[9,11]$, and fundamental to ayllu formation $[11,14]$. Remnants of this social organization persist to the present day in the Q'ero Indians community [15].

Studies about kinship of individuals buried in different chullpas provide an extraordinary opportunity to make inferences about social organization of these groups and about the significance of the kin relation in Andean communities. Recognition of kinship between individuals based solely on the archaeological record is usually impossible, and reconstructions of kinship structure in pre-Columbian archaeological sites are therefore most often based on ethnohistorical analogies and colonial records.

In this paper we present the results of ancient DNA analysis aimed at reconstructing kin relationships of individuals buried at the Tompullo 2 site. This site, located in the vicinity of the Coropuna volcano in southern Peru, was a pastoral settlement of llama and alpaca herders. Extraordinary macroscopic preservation of human remains excavated in six chullpas at this site and environmental conditions favorable for DNA preservation made this genetic kinship analysis feasible.

\section{Methods}

The study was conducted under the project "Condesuyos" carried out within the agreement between Warsaw University and the Universidad Católica de Santa Maria, coordinated by prof. Mariusz Ziółkowski director of Centre for Precolumbian Studies UW and dr Luis Augusto Belan Franco director of the Museo Arqueológico de la UCSM. Samples were collected under permissions granted by Ministerio de Cultura (formerly Instituto Nacional de Cultura) and stored in Museo Arqueológico de la UMCS.

\section{Site}

The Tompullo 2 site is located on the mountainside of Cora Cora - about 4000 meters high, in the Andaray district (dept. Arequipa, Peru; coordinates $15^{\circ} 43 / 45^{\prime} \mathrm{S}$, $72^{\circ} 44 / 50^{\prime \prime W}$ ) (Figure 1). It was investigated as part of a project to characterize the pre-Columbian settlement pattern in the region of Coropuna volcano, led by the Centre of Precolumbian Studies of the University of Warsaw. The site stretches across approximately 5 ha, and consists of several dozen buildings. The presence of oval constructions interpreted as enclosures for llamas and/or alpacas, suggests that Tompullo 2 was a pastoral settlement. The site could probably have served as a local administration center, as indicated by the presence of public building like kallanka [16]. The Tompullo 2 site was occupied for a short period of time in the Late Horizon $\left(15^{\text {th }}-16^{\text {th }}\right.$ century). It is possible that the population

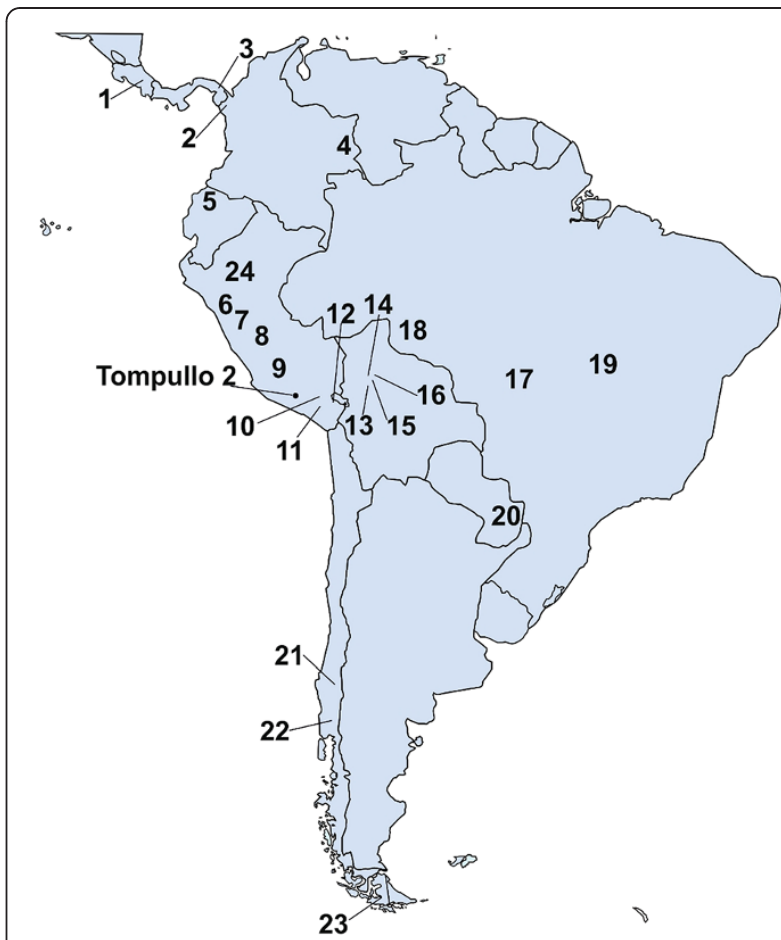

Figure 1 Map of South America with location of Tompullo 2 site and contemporary populations used in this study. 1 - Ngöebe $(n=46)$ [18], 2 - Embera $(n=44)$ [19], 3 - Wounan $(n=31)$ [20], 4 - Guahibo $(n=59)$ [21], 5 - Cayapa $(n=30)[22]$, 6 - Yungay $(n=36)$ [23], 7 - Ancash $(n=33)$ [24], 8 - San Martin $(n=23)$ [25], 9 - Tupe $(n=16)$ [23], 10 - Tayacaja $(n=61)$ [25],

11 - Arequipa ( $n=22)$ [25], 12- Puno (Aymara speaking) $(n=14)$ [23], 13 - Puno (Quechua speaking) $(n=30)$ [23], 14 - Yuracare $(n=15)$

[26], 15 - Ignaciano $(n=15)$ [26], 16 - Trinitario $(n=11)$ [26],

17 - Movima ( $n=12)$ [26], 18 - Zoro $(n=29)$ [27], 19 - Gavião

$(n=28)$ [27], $20-$ Xavante $(n=24)[27], 21-$ Ache $(n=63)[28]$, 22 - Pehuenche $(n=24)$ [29], 23 - Mapuche $(n=34)$ [29],

24 - Yaghan $(n=15)[29]$.

inhabiting the site was the mitmaq population resettled, within the confines of Inca labor system, from the other part of the Tawantinsuyu. In course of the archeological work, ten characteristic graves (chullpas) were discovered. These are rectangular buildings made of stone, up to two meters high, with a small entrance through which the bodies were placed inside [16,17]. Four chullpas (I - IV) were located in the center of the site and the other six in its close vicinity. The environmental conditions on the site were favorable for DNA preservation; the climate in the area is extremely dry, and the temperatures are low, often falling below zero. Moreover, the chullpas itself, protects bones from direct sunlight.

\section{Samples}

A total of 41 tooth or femur fragments were collected from six different chullpas from the Tompullo 2 site. The human remains had been disarticulated because of looting, 
and therefore to minimize the likelihood of taking two samples from the same individual, only teeth from the skull and pieces of left femurs were collected. To minimize post-excavation DNA degradation [30] most samples were collected directly from chullpas during field work in 2005. Face masks and gloves were worn during sampling to reduce the possibility of contamination of collected material. 14 additional samples excavated previously from the Tompullo 2 site were obtained from Museo Arqueológico de la Universidad Católica Santa María (Arequipa, Peru) (see: Additional file 1: Full list of samples from the Tompullo 2 archaeological site).

\section{Modern Amerindian sequences}

MtDNA sequences of 715 individuals from 24 contemporary Amerindian populations from South America were obtained from the literature for comparison with ancient DNA sequences. Geographic localization of these populations and source of sequences are presented in Figure 1.

\section{Contamination precautions}

DNA extraction and PCR setup were performed in a laboratory dedicated especially to ancient DNA work with positive air pressure. All staff wore lab coats, face masks and gloves. Working areas and benches were frequently cleaned with bleach and DNA ExitusPlus (Applichem). All reactions were carried out in laminar flow cabinets with HEPA filters. Only filter tips and sterile disposables were used. To eliminate the possibility of in-lab contamination negative controls were carried on with each DNA isolation procedure and PCR reaction. If PCR product was obtained in a negative control whole reaction was discarded and new aliquots of reagents were used in subsequent reactions. Additionally, mtDNA sequences and STR profiles were obtained for all the staff involved in the project.

\section{DNA extraction}

Prior to DNA extraction, each tooth or bone fragment was submerged in bleach $(6 \% \mathrm{w} / \mathrm{v}$ sodium hypochlorite) for 1 minute, cleaned with a sterile toothbrush and rinsed with $\mathrm{ddH}_{2} \mathrm{O}$. Afterwards, samples were UV irradiated for at least 20 minutes on each side, and pulverized in a cryogenic mill (Spex CentriPrep). Up to $500 \mathrm{mg}$ of bone or tooth powder was incubated overnight at $40^{\circ} \mathrm{C}$ in $1.6 \mathrm{ml}$ of extraction buffer (0.5 M EDTA, $0.7 \mathrm{mg}$ of proteinase $\mathrm{K}$ (20 mg/ml) (Bioline), $0.1 \mathrm{M} \mathrm{DTT,} 50 \mathrm{mM} \mathrm{PTB,} \mathrm{0.5 \%}$ $\mathrm{N}$-Lauryl sarcosine) with constant agitation. Following incubation, the supernatant was extracted with phenol: chloroform:isoamyl alcohol (25:24:1, v:v:v), followed by two chloroform DNA extractions and isopropanol precipitation [31]. After precipitation, DNA was resuspended in $60 \mu \mathrm{l}$ of $\mathrm{ddH}_{2} \mathrm{O}$ (Fluka). At least two independent DNA extractions were performed from each specimen.

\section{MtDNA amplification}

For initial screening, a $146 \mathrm{bp}$ amplicon of the mtDNA control region (mtCR) was amplified using the primer pair $16090 \mathrm{~F}$ (5'-ATT TCG TAC ATT ACT GCC AG-3') and 16236R (5'-GTG TGA TAG TTG AGG GTT GA-3'). If this product was successfully amplified, a longer (330 bp) fragment, encompassing positions 16111-16400 (HVRI), was amplified using the same forward primer $16090 \mathrm{~F}$ with a different reverse primer (16420R; 5'-TGA TTT CAC GGA GGA TGG TG-3'). Each reaction mix $(25 \mu \mathrm{l})$ contained $0.2 \mu \mathrm{M}$ of each primer, $2 \mathrm{U}$ of SAHARA Taq polymerase (Bioline), $0.1 \mathrm{M}$ BSA, $10 \mathrm{mM}$ dNTPs, $2.5 \mathrm{mM} \mathrm{MgCl} 2$ and $1.5 \mu$ of extracted DNA. Cycling conditions consisted of an initial denaturation of $5 \mathrm{~min}$. at $95^{\circ} \mathrm{C}$ followed by 40 cycles of $30 \mathrm{sec}$. at $95^{\circ} \mathrm{C}$, $45 \mathrm{sec}$. at $56^{\circ} \mathrm{C}, 1 \mathrm{~min}$. at $72^{\circ} \mathrm{C}$ followed by final extension of $7 \mathrm{~min}$. at $72^{\circ} \mathrm{C}$. PCR products were purified with SureClean Kit (Bioline) and sequenced using an ABI PRISM 3730 automated sequencer in DNA Sequencing \& Oligonucleotide Synthesis Lab "Oligo.pl”. At least two PCR reactions were performed on each DNA sample. To ensure that the PCR products were homogenous and that the obtained sequences did not contain errors due to post-mortem DNA modification, each PCR product was cloned with the PCR Cloning Kit (Qiagen) according to the manufacturer's instruction. One to ten clones were sequenced for each PCR product and the consensus sequence for each sample was generated with $50 \%$ majority rule (See: Additional file 2: Results of cloning of PCR products).

\section{Molecular sex determination}

Each sample that yielded a reliable mtDNA sequence was also used for genetic sex determination. Fragments of the amelogenin and SRY genes were coamplified in a duplex PCR reaction with fluorescent labeled primers. Previously published primer sequences were used XYF: $5^{\prime}$ - Tamra CCC TGG GCT CTG TAA AGA ATA GTG - 3'; XYR: $5^{\prime}$ - ATC AGA GCT TAA ACT GGG AAG CTG -3' resulting in either a $106 \mathrm{bp}$ product (female) or both 106 and 112 bp products (male). For SRYF: $5^{\prime}$ - Tamra - GCA CTT CGC TGC AGA GTA CCG A $-3^{\prime}$ and SRYR: $5^{\prime}-$ ATA AGT ATC GAC CTC GTC GGA A - 3' (resulting in a male specific $93 \mathrm{bp}$ product) [32,33]. PCR reactions were carried out with the Multiplex PCR Kit (Qiagen), $25 \mu \mathrm{l}$ of reaction mix contained 1x PCR Master Mix, 0.1 M BSA, $0.2 \mu \mathrm{M}$ of XY primers, $0.1 \mu \mathrm{M}$ SRY primers and $1.5 \mu \mathrm{l}$ of DNA extract. Cycling conditions consisted of an initial denaturation of $15 \mathrm{~min}$. at $95^{\circ} \mathrm{C}$ followed by 40 cycles of 30 sec. at $95^{\circ} \mathrm{C}, 90$ sec. at $61^{\circ} \mathrm{C}, 45 \mathrm{sec}$. at $72^{\circ} \mathrm{C}$ followed by a final extension for $30 \mathrm{~min}$. at $60^{\circ} \mathrm{C}$. PCR products were electrophoresed in 3\% agarose gels and analyzed on $\mathrm{ABI}$ PRISM 3730xl automated sequencer and Peak Scanner 
software (Applied Biosystems). At least two independent PCR reactions were performed for each DNA sample.

\section{Autosomal STR amplification}

Twelve autosomal microsatellites (TH01, FGA, CSF1PO, D21S11, TPOX, D5S818, D8S1179, D16S539, vWA, D18S51, D13S317) were amplified in 3 multiplex reactions for each sample which had previously given reproducible mtDNA sequencing results. Primer sequences and final concentrations were in accordance with Butler and coworkers [34]. Reduced amplicon size multiplexes were specially designed for work with highly degraded DNA [34]. Moreover, extensive validation studies were undertaken for these sets $[35,36]$. PCR reactions were carried out in $25 \mu$ lof reaction mix containing 1x PCR Master Mix, $1.5 \mu \mathrm{l}$ of DNA extract, 0.1 M BSA and appropriate concentrations of primers. Cycling conditions consisted of an initial denaturation of $15 \mathrm{~min}$. at $95^{\circ} \mathrm{C}$ followed by 40 cycles of $30 \mathrm{sec}$. at $95^{\circ} \mathrm{C}, 90 \mathrm{sec}$. at $60^{\circ} \mathrm{C}, 45 \mathrm{sec}$. at $72^{\circ} \mathrm{C}$ followed by a final extension for $30 \mathrm{~min}$. at $60^{\circ} \mathrm{C}$. PCR products were analyzed on ABI PRISM 3730xl automated sequencer in Oligo.pl and Peak Scanner software (Applied Biosystems). For each locus, alleles were assigned according to allelic ladders from STR Base (http://www.cstl.nist. gov/div831/strbase). At least two independent PCR reactions were performed for each DNA sample. Alleles were scored when they appeared at least twice.

\section{Y-chromosome STR amplification}

All the samples for which sex had been determined as male, were also typed for 16 Y-chromosome microsatellites (DYS456, DYS389I,II, DYS390, DYS458, DYS19, DYS385a,b, DYS393, DYS391, DYS439, DYS635, DYS392, H4, DYS437, DYS438 and DYS448) with AmpFeSTR Kit (Applied Biosystems) according to the manufacturer's recommendations with the exception that the number of PCR cycles was increased to 40. AmpFeSTR Kit coamplifies 16 loci in one reaction and some of the amplicons are longer than $200 \mathrm{bp}$. As we encountered problems with amplification of longer amplicons with AmpFlSTR Kit, all samples were additionally subjected to amplification of 15 Y-chromosome STRs with 3 "home made" multiplexes. Primers used in these multiplexes were designed to minimize the lengths of amplicons of each locus (see: Additional file 3: Details of Y chromosome STR multiplexes design and validation). At least two independent PCR reactions were performed from each DNA sample. Alleles were scored when they appeared at least twice.

\section{Statistical analysis}

Pairwise genetic distances $\left(\mathrm{F}_{\mathrm{ST}}\right.$ based on mtDNA haplotype frequencies) between populations [37] were estimated with ARLEQUIN v. 3.0 software [38]. In this analysis, sequence length was cut down to $252 \mathrm{bp}$ (16111-16362) to fit sequences from the literature. A matrix of pairwise distances was presented as an MDS plot constructed with SPSS software. For the microsatellite data, tests for HardyWeinberg equilibrium, $\mathrm{H}_{\mathrm{O}}, \mathrm{H}_{\mathrm{E}}$ and $\mathrm{Na}$, were computed with ARLEQUIN v. 3.0 software.

Molecular data on mtDNA, autosomal and Y chromosomal genetic systems allow inference of kinship structure between individuals buried at Tompullo 2 site. MtDNA could provide evidence of maternal relationships. However HVRI haplotypes are considered as a weak marker for human identification and establishing kinship between individuals $[39,40]$, as homoplasmy leads to identical haplotypes being carried by unrelated individuals. The "counting method" is usually employed to evaluate the significance of mtDNA HVRI match between the individuals [41,42]. The number of scores of desired haplotype in the database gives the probability that two haplotypes are identical by chance. Here we used a database with 715 sequences of modern Native Americans (Figure 1) to calculate the probability of identity of haplotype by chance.

To estimate pairwise relationships between each pair of individuals based on microsatellite data two relatedness coefficients were calculated. The Queller and Goodnight coefficient $\left(\mathrm{R}_{\mathrm{QG}}\right)$ [43] was calculated with Relatedness v. 5.0.8 software [44], while the Lynch and Ritland coefficient $\left(R_{L R}\right)$ [45] was calculated in GeneAlex v. 6.4 software [46]. Recent comparisons of the performance of relatedness coefficients suggest that use of Lynch and Ritland's estimator results in the smallest sampling variances, but this estimator is sensitive for sample size and overall population relatedness [47]. Queller and Goodnight's coefficient performs better when allele frequencies used in calculations are based on typing of a small and putatively related group of individuals which is the case for the samples from Tompullo 2 [48].

\section{Results \\ Mitochondrial DNA}

Of the 41 samples collected at Tompullo 2 site, we succeeded in amplification and sequencing of the $330 \mathrm{bp}$ mtCR segment from 27 individuals. Amplification products in negative controls were obtained in three PCR reactions, these were discarded from further analyses. Two samples were rejected from further analysis because of inconsistencies in the sequences of the clones resulting from either DNA damage or in-lab contamination. One pair of samples (T2CH81 and T2CH82) showed identical mtDNA and autosomal STR genotypes. These samples were tooth and femur fragments collected from one grave and there is a high possibility that they belong to the same individual. Thus, one of these samples was excluded from further analysis.

Based on characteristic substitutions, each sequence was assigned to one of four major mtDNA haplogroups 
(Hgs) found in South America [49,50]. Out of 24 obtained sequences, 2 were assigned to haplogroup A2 (8.3\%), 17 (70.8\%) to haplogroup B2, 1 (4.2\%) to C1 and 4 (16.7\%) to $\mathrm{D} 1$. In sequences that belong to haplogroup $\mathrm{B} 2$, a diagnostic substitution $\mathrm{T} 16189 \mathrm{C}$ resulted in the formation of a poly-C stretch (nt. 16184-16193), subsequently leading to poly-C length polymorphism in some sequences. This could have been a result of polymerase slippage during PCR or cloning [51], and thus poly-C length variation at this site was excluded from the analysis. Similarly, substitutions A16182C and A16183C were excluded because of possible dependence on the T16189C substitution [20,51]. HVRI haplotypes obtained in this study are presented in Table 1. Sequences were deposited in GenBank under accession numbers JN833681 - JN833704. Genetic distances

\begin{tabular}{|c|c|c|}
\hline Sample & HVR-I (16111-16362) & $\mathrm{Hg}$ \\
\hline \multicolumn{3}{|c|}{ Tompullo 2} \\
\hline \multicolumn{3}{|c|}{ Chullpa I } \\
\hline $\mathrm{T} 2 \mathrm{CH} 12$ & 189 C, 217 C & $\mathrm{B}$ \\
\hline $\mathrm{T} 2 \mathrm{CH} 13$ & $223 \mathrm{~T}, 286 \mathrm{~T}, 325 \mathrm{C}, 362 \mathrm{C}$ & $\mathrm{D}$ \\
\hline $\mathrm{T} 2 \mathrm{CH} 14$ & 189 C, 217 C & $\mathrm{B}$ \\
\hline $\mathrm{T} 2 \mathrm{CH} 16$ & $168 \mathrm{~T}, 189 \mathrm{C}, 217 \mathrm{C}$ & B \\
\hline \multicolumn{3}{|c|}{ Chullpa III } \\
\hline $\mathrm{T} 2 \mathrm{CH} 33$ & $168 \mathrm{~T}, 189 \mathrm{C}, 217 \mathrm{C}$ & B \\
\hline T2CH37 & $168 \mathrm{~T}, 189 \mathrm{C}, 217 \mathrm{C}$ & B \\
\hline $\mathrm{T} 2 \mathrm{CH} 38$ & 111 T, 217 C, 223 T, 290 T, 319A, 362 C & A \\
\hline $\mathrm{T} 2 \mathrm{CH} 39$ & $223 \mathrm{~T}, 286 \mathrm{~T}, 325 \mathrm{C}, 362 \mathrm{C}$ & $\mathrm{D}$ \\
\hline \multicolumn{3}{|c|}{ Chullpa VI } \\
\hline $\mathrm{T} 2 \mathrm{CH} 61$ & $168 \mathrm{~T}, 189$ C, 217 C, 295 T & B \\
\hline \multicolumn{3}{|c|}{ Chullpa VII } \\
\hline $\mathrm{T} 2 \mathrm{CH} 71$ & 189 C, 223 T, 289 C, 310A, 325 C, 327 T & C \\
\hline $\mathrm{T} 2 \mathrm{CH} 72$ & 178 C, 189 C, 217 C & B \\
\hline $\mathrm{T} 2 \mathrm{CH} 73$ & 178 C, 189 C, 217 C & B \\
\hline $\mathrm{T} 2 \mathrm{CH} 711$ & 189 C, 217 C, 247 G, $261 \mathrm{~T}$ & B \\
\hline $\mathrm{T} 2 \mathrm{CH} 712$ & 189 C, 217 C, 247 G, 261 T & B \\
\hline $\mathrm{T} 2 \mathrm{CH} 715$ & $168 \mathrm{~T}, 189$ C, 217 C, $295 \mathrm{~T}$ & B \\
\hline $\mathrm{T} 2 \mathrm{CH} 719$ & $223 \mathrm{~T}, 325 \mathrm{C}, 362 \mathrm{C}$ & $\mathrm{D}$ \\
\hline $\mathrm{T} 2 \mathrm{CH} 728$ & 178 C, 189 C, 217 C, 218 T & B \\
\hline T2CH729 & $223 \mathrm{~T}, 325 \mathrm{C}, 362 \mathrm{C}$ & $\mathrm{D}$ \\
\hline $\mathrm{T} 2 \mathrm{CH} 730$ & 111 T, 217 C, 223 T, 290 T, 319A, 362 C & A \\
\hline \multicolumn{3}{|c|}{ Chullpa VIII } \\
\hline $\mathrm{T} 2 \mathrm{CH} 82$ & 189 C, 217 C, 289 G & B \\
\hline $\mathrm{T} 2 \mathrm{CH} 83$ & $168 \mathrm{~T}, 189 \mathrm{C}, 217 \mathrm{C}$ & B \\
\hline $\mathrm{T} 2 \mathrm{CH} 84$ & $168 \mathrm{~T}, 189$ C, 217 C, $295 \mathrm{~T}$ & B \\
\hline $\mathrm{T} 2 \mathrm{CH} 85$ & $168 \mathrm{~T}, 189$ C, 217 C, $295 \mathrm{~T}$ & B \\
\hline T2CH86 & $168 \mathrm{~T}, 189$ C, 217 C, 295 T & $\mathrm{B}$ \\
\hline
\end{tabular}

between populations were estimated on the basis of pairwise $\mathrm{F}_{\mathrm{ST}}$ (Figure 2, Additional file 4: Matrix of genetic distances $\left(\mathrm{F}_{\mathrm{ST}}\right)$ between Tompullo 2 and modern South American populations). Inhabitants of Tompullo 2 exhibit shorter distances to representatives of the Andean populations than to non-Andean ones, such as Peruvian populations from Puno, San Martin, Ancash, and Yungay. The shortest distances were observed between Tompullo 2 and Arequipa and Tayacaja populations (0.0294 and 0.0256, respectively). However, among Andean populations Fisher's exact tests show significant differences in haplogroup frequencies between Tompullo2 and Tayacaja ( $p=0.0273)$ as well as between Tompullo 2 and Puno (Quechua speaking) populations $(p=0.0427)$.

\section{Autosomal microsatellites}

Each sample, for which mtDNA sequence was obtained, was typed for 12 autosomal microsatellites. Complete or nearly complete allelic profiles were obtained for 16 samples (Table 2). For each specimen, up to six PCR reactions from two different DNA extracts were performed in order to ensure the reliability of typing. Nevertheless, for locus D21S11, which has the longest amplicons, there were no amplification products in the case of three samples. Samples for which there were more than two loci of nonreplicable typing were excluded from analysis. Expected $\left(\mathrm{H}_{\mathrm{E}}\right)$ and observed $\left(\mathrm{H}_{\mathrm{O}}\right)$ heterozygosity were 0.632 and 0.683 , respectively $\left(\mathrm{H}_{\text {Mean }}=0.656\right)$. The mean number of alleles per locus $\left(\mathrm{N}_{\mathrm{A}}\right)$ were 4.25 . The mean heterozygosity obtained for the studied population falls within the range reported for Andean populations in a massive study by Wang and co-workers [52]. However, mean allele number (Na) is smaller than reported for contemporary and preColumbian South American populations (8.9 for Puna region, Argentina [53], 6.7 for Pampa Grande site, Salta, Argentina [54]). The population from Tompullo 2 did not display deviations from Hardy-Weinberg equilibrium.

\section{Sex determination and $\mathrm{Y}$ chromosome microsatellites}

Out of 25 samples tested for biological sex 16 yielded reproducible results (Table 2). 11 samples were determined as males and all were subsequently subjected to Y chromosome microsatellite typing (Table 3 ). The most complete profiles were obtained for individuals from chullpas I and VIII. In case of sample T2CH729 results were obtained only for five loci. Overall six distinct $\mathrm{Y}$ chromosome lineages were identified. Different Y chromosome lineages were present in each grave. In chullpa I, all three males carried the same genotype (alleles at 14 loci were obtained for all the three individuals), the same was in the case of chullpa VIII (at 11 loci). A different situation was observed in chullpa VII where three distinct lineages were present amongst four individuals. 


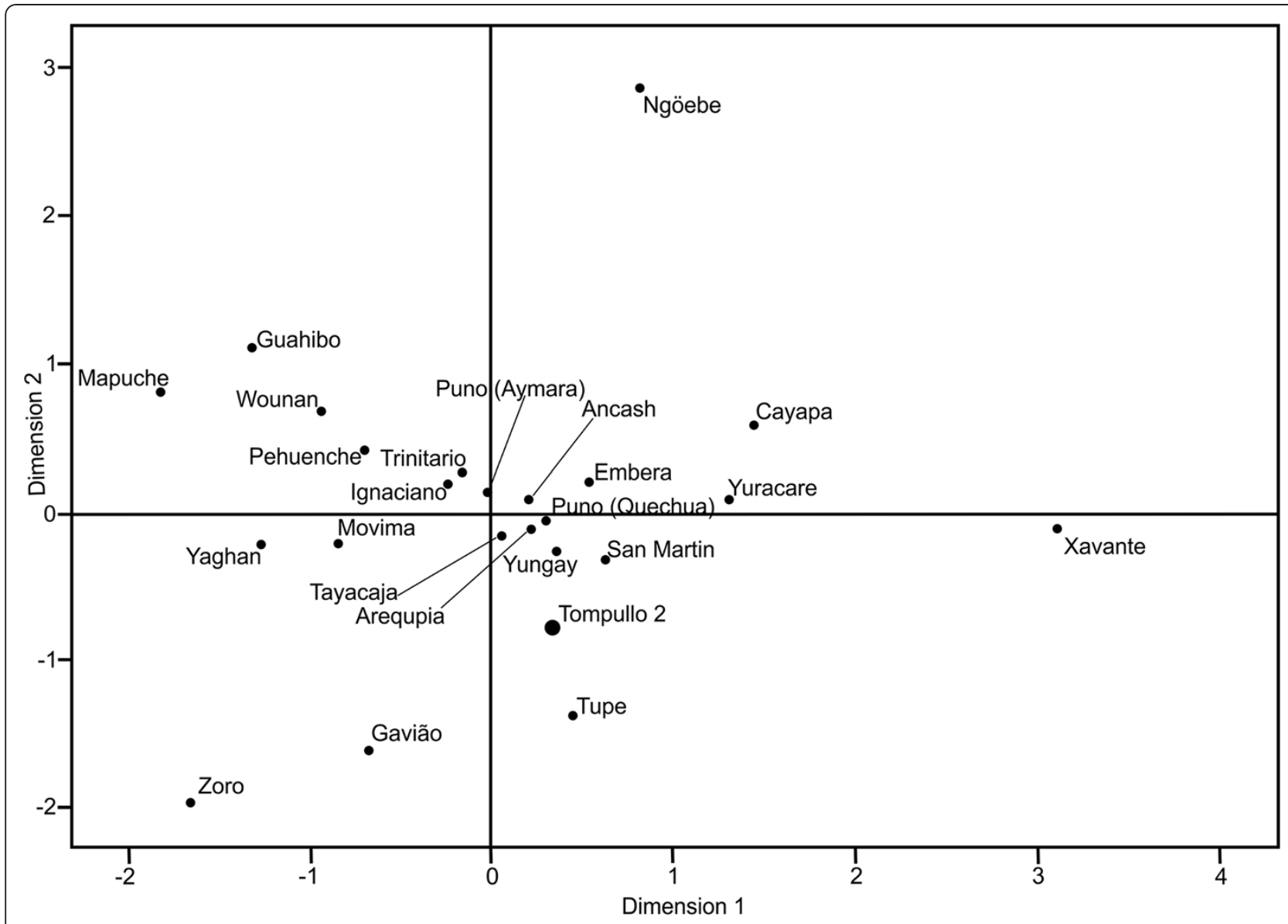

Figure 2 Multidimensional Scaling plot based on pairwise distances $\left(F_{S T}\right)$ between Tompullo 2 and 23 contemporary populations. The Ache population was very divergent from others and it was not used in multidimensional scaling analysis to retain figure legible.

\section{Genetic relationships between individuals}

Eight distinct mtDNA haplotypes were shared between two or more individuals from the Tompullo 2 site (Table 4). The most common one (16168 T, 16189 C, 16217 C, $16295 \mathrm{~T}$ ) was present in five individuals buried in three different chullpas. For haplotypes $16189 \mathrm{C}, 16217 \mathrm{C}$ and $16223 \mathrm{~T}, 16325 \mathrm{C}, 16362 \mathrm{C}$ which were carried by two pairs of individuals (T2CH12, T2CH14 and T2CH719, $\mathrm{T} 2 \mathrm{CH} 729$, respectively) the probabilities of identity by chance were 0.094 and 0.057 high, respectively, but close relatedness between these pairs was confirmed by autosomal microsatellites analysis (see below). Haplotype 16168 T, 16189 C, 16217 C, carried by four individuals from Tompullo 2, was found 17 times in the database; the probability of encountering the identical allele in two individuals by chance equals 0.024 . Only two out of the four individuals (T2CH16 and T2CH83) were successfully typed for autosomal microsatellites, and the calculated relatedness coefficients $\left(\mathrm{R}_{\mathrm{QG}}\right.$ and $\left.\mathrm{LR}=-0.01\right)$ does not confirm close relationship between those individuals. Thus based on available data, those individuals were not considered as maternal relatives. In all other cases, frequency of haplotype in the database varies between 0 (haplotypes $16189 \mathrm{C}$, $16217 \mathrm{C}, 16247 \mathrm{G}, 16261 \mathrm{~T}$ and $16223 \mathrm{~T}, 16286 \mathrm{~T}$, $16325 \mathrm{C}, 16362 \mathrm{C}$ ) and 0.001 (16168 T, 16189 C, 16217 C, $16295 \mathrm{~T}$ ) and the individuals carrying these haplotypes were considered to be maternal relatives (Table 4).

Due to the uniparental mode of inheritance of mtDNA, all maternal relatives possess identical haplotype and it is impossible to infer the degree of relationship between individuals. We estimated the degree of relatedness between these individuals by calculating $\mathrm{R}$ coefficients based on microsatellite data. Using both estimators, related pairs of individuals were found buried in one chullpa (e.g. individuals $\mathrm{T} 2 \mathrm{CH} 12$ and $\mathrm{T} 2 \mathrm{CH} 14$ that share the same mtDNA haplotype and have $R_{\mathrm{QG}}=0.54$ and $\mathrm{R}_{\mathrm{LR}}=0.19$ or T2CH84 and T2CH86 with the same mtDNA haplotype and $\mathrm{R}_{\mathrm{QG}}=0.39$ and $\mathrm{R}_{\mathrm{LR}}=0.15$ ), as well as buried in different chullpas (e.g. individuals $\mathrm{T} 2 \mathrm{CH} 13$ and $\mathrm{T} 2 \mathrm{CH} 86$ with different mtDNA haplotypes and $\mathrm{R}_{\mathrm{QG}}=0.39$ and $\mathrm{R}_{\mathrm{LR}}=0.1$ 
Table 2 Results of sex determination and genotypes of 12 autosomal microsatellites of 16 samples from Tompullo 2 site

\begin{tabular}{|c|c|c|c|c|c|c|c|c|c|c|c|c|c|}
\hline Sample & Sex & TH01 & FGA & CSF1PO & D21S11 & TPOX & D7S820 & D5S818 & D8S179 & D16S539 & vWA & D18S51 & D13S317 \\
\hline \multicolumn{14}{|l|}{ chullpa I } \\
\hline $\mathrm{T} 2 \mathrm{CH} 12$ & $\mathrm{~F}$ & $7 / 7$ & $24 / 26$ & $13 / 13$ & $32.2 / 32.2$ & $13 / 13$ & $12 / 13$ & $11 / 11$ & $13 / 15$ & $10 / 11$ & $17 / 17$ & $16 / 16$ & $10 / 13$ \\
\hline $\mathrm{T} 2 \mathrm{CH} 13$ & M & $7 / 10$ & $20 / 28$ & $11 / 13$ & $30 / 32.2$ & $9 / 9$ & $11 / 11$ & $7 / 11$ & $13 / 16$ & $13 / 13$ & $17 / 17$ & $13 / 18$ & $10 / 10$ \\
\hline $\mathrm{T} 2 \mathrm{CH} 14$ & M & $7 / 7$ & $20 / 24$ & $12 / 13$ & $31.2 / 32.2$ & $12 / 13$ & $11 / 12$ & $10 / 11$ & $13 / 15$ & $10 / 13$ & $17 / 17$ & $16 / 16$ & $10 / 13$ \\
\hline \multicolumn{13}{|l|}{ chullpa II } & $10 / 13$ \\
\hline $\mathrm{T} 2 \mathrm{CH} 38$ & M & $7 / 10$ & $25 / 26$ & $13 / 13$ & $-/-$ & $9 / 9$ & $10 / 10$ & $11 / 11$ & $13 / 16$ & $13 / 13$ & $16 / 17$ & $13 / 14$ & $10 / 10$ \\
\hline T2CH39 & $\mathrm{F}$ & $7 / 10$ & $25 / 25$ & $13 / 13$ & $32.2 / 32.2$ & $10 / 13$ & $11 / 11$ & $7 / 11$ & $13 / 14$ & $10 / 12$ & $16 / 17$ & $15 / 16$ & $10 / 13$ \\
\hline \multicolumn{14}{|c|}{ chullpa VII } \\
\hline $\mathrm{T} 2 \mathrm{CH} 73$ & $\mathrm{~F}$ & $7 / 10$ & $25 / 26$ & $13 / 13$ & $32.2 / 32.2$ & $9 / 13$ & $12 / 12$ & $7 / 11$ & $13 / 14$ & $11 / 11$ & $16 / 19$ & $14 / 18$ & $10 / 10$ \\
\hline T2Ch715 & M & $7 / 10$ & $25 / 26$ & $13 / 13$ & $32.2 / 32.2$ & $9 / 13$ & $12 / 12$ & $7 / 7$ & $-/-$ & $10 / 11$ & $17 / 19$ & $13 / 14$ & $10 / 12$ \\
\hline T2CH719 & M & $7 / 10$ & $20 / 26$ & $12 / 13$ & $29 / 32.2$ & $9 / 13$ & $11 / 12$ & $7 / 11$ & $13 / 15$ & $11 / 14$ & $17 / 17$ & $14 / 16$ & $10 / 13$ \\
\hline T2CH729 & M & $7 / 10$ & $20 / 20$ & $12 / 13$ & $-1-$ & $9 / 13$ & $12 / 12$ & $7 / 11$ & $13 / 15$ & $11 / 14$ & $17 / 17$ & $14 / 16$ & $10 / 13$ \\
\hline T2CH730 & M & $7 / 10$ & $20 / 26$ & $12 / 13$ & $30.2 / 32.2$ & $9 / 9$ & $11 / 12$ & $7 / 11$ & $15 / 15$ & $11 / 11$ & $17 / 17$ & $13 / 19$ & $10 / 11$ \\
\hline \multicolumn{14}{|c|}{ chullpa VIII } \\
\hline $\mathrm{T} 2 \mathrm{CH} 82$ & M & $6 / 7$ & $20 / 26$ & $12 / 13$ & $30.2 / 31$ & $9 / 13$ & $12 / 12$ & $11 / 11$ & $15 / 16$ & $11 / 13$ & $16 / 17$ & $15 / 16$ & $10 / 10$ \\
\hline T2CH83 & $\mathrm{F}$ & $6 / 7$ & $21 / 25$ & $13 / 13$ & $32.2 / 32.2$ & $9 / 12$ & $11 / 12$ & $11 / 11$ & $13 / 16$ & $12 / 13$ & $16 / 17$ & $13 / 15$ & $10 / 10$ \\
\hline $\mathrm{T} 2 \mathrm{CH} 84$ & M & $6 / 10$ & $26 / 28$ & $12 / 13$ & $30 / 32.2$ & $9 / 12$ & $11 / 11$ & $7 / 11$ & $13 / 15$ & $12 / 14$ & $17 / 17$ & $14 / 16$ & $10 / 11$ \\
\hline $\mathrm{T} 2 \mathrm{CH} 85$ & $\mathrm{~F}$ & $6 / 10$ & $26 / 28$ & $12 / 13$ & $31.2 / 33.2$ & $9 / 13$ & $10 / 12$ & $7 / 11$ & $15 / 16$ & $13 / 14$ & $17 / 17$ & $13 / 16$ & $10 / 12$ \\
\hline T2CH86 & M & $10 / 10$ & $26 / 26$ & $12 / 13$ & $30 / 30$ & $9 / 13$ & $11 / 11$ & $7 / 7$ & $13 / 16$ & $11 / 13$ & $17 / 17$ & $13 / 16$ & $10 / 11$ \\
\hline
\end{tabular}

or T2CH38 and T2CH83 with $\mathrm{R}_{\mathrm{QG}}=0.43$ and $\left.\mathrm{R}_{\mathrm{LR}}=0.07\right)$. See Additional file 5: Matrix of relatedness coefficients $\left(\mathrm{R}_{\mathrm{QG}}\right.$ and $\mathrm{R}_{\mathrm{LR}}$ ) estimated for individuals from Tompullo 2 site, for all $\mathrm{R}$ coefficients.
For both estimators the mean relatedness calculated for all pairs of individuals buried in the same grave $\left(\mathrm{R}_{\mathrm{QG}}=0.082\right.$ and $\mathrm{R}_{\mathrm{LR}}=0.024$ ) was significantly (two tailed t-test, $\mathrm{p}=0.0116$ and $\mathrm{p}=0.0049$ ) higher than for all pairs of

Table 3 Genotypes of 16 Y chromosome microsatellites obtained for 11 individuals from Tompullo 2 site

\begin{tabular}{|c|c|c|c|c|c|c|c|c|c|c|c|c|c|c|c|c|}
\hline Individual & 456 & 3891 & 390 & 38911 & 458 & 19 & $385 a, b$ & 393 & 391 & 439 & 635 & 392 & $\mathrm{H} 4$ & 437 & 438 & 448 \\
\hline \multicolumn{17}{|l|}{ Chullpa I } \\
\hline $\mathrm{T} 2 \mathrm{CH} 13$ & 15 & 14 & 23 & 30 & 16 & 13 & $15 / 19$ & 14 & 10 & 14 & 21 & 16 & 12 & 14 & 11 & 20 \\
\hline $\mathrm{T} 2 \mathrm{CH} 14$ & 15 & 14 & 23 & 30 & 16 & 13 & $15 / 19$ & 14 & 10 & 14 & - & - & 12 & 14 & 11 & 20 \\
\hline $\mathrm{T} 2 \mathrm{CH} 16$ & 15 & 14 & 23 & 30 & 16 & 13 & $15 / 19$ & 14 & 10 & 14 & 21 & - & 12 & 14 & 11 & 20 \\
\hline \multicolumn{17}{|l|}{ Chullpa III } \\
\hline T2CH38 & 15 & 14 & - & - & 16 & 16 & $15 / 19$ & - & - & 11 & - & 16 & - & 15 & - & 18 \\
\hline \multicolumn{17}{|l|}{ Chullpa VII } \\
\hline T2CH715 & 16 & - & - & - & 16 & - & - & 10 & 10 & 11 & - & 16 & - & 16 & - & - \\
\hline T2CH719 & 15 & 14 & - & - & 16 & 13 & $15 / 19$ & 14 & 10 & 13 & - & - & 13 & 14 & - & - \\
\hline T2CH730 & 15 & 14 & - & 30 & 16 & 13 & $15 / 19$ & 14 & 10 & 13 & 22 & 16 & 13 & 14 & 11 & 20 \\
\hline T2CH729 & - & 14 & - & - & 16 & - & - & - & - & - & - & 14 & - & 13 & - & - \\
\hline \multicolumn{17}{|l|}{ Chullpa VIII } \\
\hline T2CH81 & 15 & 13 & 23 & 30 & 16 & 13 & $15 / 18$ & 14 & 10 & 13 & 21 & 16 & 12 & 14 & 11 & 20 \\
\hline T2CH84 & 15 & 13 & 23 & 30 & 16 & 13 & $15 / 18$ & 14 & 10 & 13 & - & - & 12 & 14 & - & 20 \\
\hline T2Ch86 & 15 & 13 & 23 & - & 16 & 13 & $15 / 18$ & 14 & 10 & 13 & 21 & 16 & 12 & 14 & - & 20 \\
\hline
\end{tabular}


Table 4 Individuals with identical mtDNA haplotypes

\begin{tabular}{|c|c|c|c|c|c|}
\hline Individuals & Chullpa & Haplotype & In database & Frequency & $95 \% \mathrm{Cl}$ \\
\hline $\mathrm{T} 2 \mathrm{CH} 12$ & 1 & 189 C, 217 C & 67 & 0.094 & $0.072-0.115$ \\
\hline $\mathrm{T} 2 \mathrm{CH} 14$ & I & & & & \\
\hline $\mathrm{T} 2 \mathrm{CH} 719$ & VII & $223 \mathrm{~T}, 325 \mathrm{C}, 362 \mathrm{C}$ & 40 & 0.056 & $0.039-0.073$ \\
\hline T2CH729 & VII & & & & \\
\hline $\mathrm{T} 2 \mathrm{CH} 72$ & VII & 178 C, 189 C, 217 C & 1 & 0.001 & $0-0.004$ \\
\hline $\mathrm{T} 2 \mathrm{CH} 73$ & VII & & & & \\
\hline $\mathrm{T} 2 \mathrm{CH} 16$ & I & $168 \mathrm{~T}, 189 \mathrm{C}, 217 \mathrm{C}$ & 17 & 0.024 & $0.013-0.035$ \\
\hline $\mathrm{T} 2 \mathrm{CH} 33$ & III & & & & \\
\hline $\mathrm{T} 2 \mathrm{CH} 37$ & III & & & & \\
\hline $\mathrm{T} 2 \mathrm{CH} 83$ & VIII & & & & \\
\hline $\mathrm{T} 2 \mathrm{CH} 38$ & III & 111 T, 217 C, 223 T, 290 T, 319A, 362 C & 1 & 0.001 & $0-0.004$ \\
\hline $\mathrm{T} 2 \mathrm{CH} 730$ & VII & & & & \\
\hline T2CH61 & $\mathrm{Vl}$ & $168 \mathrm{~T}, 189$ C, 217 C, 295 T & 1 & 0.001 & $0-0.004$ \\
\hline $\mathrm{T} 2 \mathrm{CH} 715$ & VII & & & & \\
\hline $\mathrm{T} 2 \mathrm{CH} 84$ & VIII & & & & \\
\hline T2CH85 & VIII & & & & \\
\hline T2CH86 & VIII & & & & \\
\hline $\mathrm{T} 2 \mathrm{CH} 711$ & VII & 189 C, 217 C, 247 G, 261 T & 0 & 0 & $0-0.004$ \\
\hline $\mathrm{T} 2 \mathrm{CH} 712$ & VII & & & & \\
\hline $\mathrm{T} 2 \mathrm{CH} 13$ & I & $223 \mathrm{~T}, 286 \mathrm{~T}, 325 \mathrm{C}, 362 \mathrm{C}$ & 0 & 0 & $0-0.004$ \\
\hline T2CH39 & III & & & & \\
\hline
\end{tabular}

Number of the same haplotypes in database of 715 sequences, frequency of each haplotype and $95 \%$ confidence intervals.

individuals buried in different graves $\left(\mathrm{R}_{\mathrm{QG}}=-0.073\right.$ and $\left.R_{L R}=-0.05\right)$.

\section{Discussion}

Appropriate verification of results is crucial in all DNA studies of human remains [55-58], as modern DNA contamination and post-mortem DNA damage can lead to biased results and misleading conclusions [59]. In this study strict precautions were taken to avoid the contamination of samples with modern DNA during sampling and laboratory analysis, with appropriate effort to exclude possible errors in the obtained sequences. The skeletal material from the Tompullo 2 site was of extraordinary macroscopic preservation and the environmental conditions at the site strongly favored DNA preservation. Data from autosomal and Y chromosome microsatellite typing also strongly support the authenticity of the results as no triple peaks were observed throughout the analysis. Identical profiles obtained for samples $\mathrm{T} 2 \mathrm{CH} 81$ and T2CH82 were most probably an effect of sampling both teeth and femur from one individual. Mean heterozygosity is comparable to that reported for modern Amerindian populations, which indicates that no large allele drop outs occurred during microsatellite typing.

Mitochondrial DNA analysis points to the Andean origin of the studied population. Inhabitants of Tompullo 2 exhibit a high frequency of haplogroup B2, characteristic for most contemporary and pre-Columbian Andean populations $[23,25,60]$. Based on genetic distance $\left(\mathrm{F}_{\mathrm{ST}}\right)$, Tompullo 2 residents were most similar to contemporary Andean populations, especially those from the same geographic area. Samples from contemporary populations were collected from Quechua or Aymara speakers from Peruvian cities (Puno, Yungay, San Martin) [23,25] and from farming communities, which settled in the region before the arrival of Europeans (Arequipa, Tayacaja, Ancash) $[24,61]$. Despite differences in haplogroup frequencies between Tompullo 2, Tayacaja and Quechua speakers from Puno, our data suggest continuity of populations inhabiting the region for at least the last five hundred years, without major change in mtDNA diversity. This confirms that the impact of European colonization on Native Amerindian populations was relatively small in the Andean region, and is congruent with historical data [62].

Kinship analyses using both uniparentally (mtDNA, YSTRs) and biparentally (autosomal STRs) inherited markers indicate a complex pattern of relationships between individuals. On the one hand mtDNA and autosomal microsatellite analyses indicate closely related individuals buried in the same, as well as in different, chullpas. However, mean relatedness coefficients between individuals 
buried in the same chullpa were significantly higher than those between pairs of individuals buried in different chullpas, suggesting that degree of relationship was one of the factors influencing mortuary practices. Moreover, $\mathrm{Y}$ chromosome microsatellites revealed that in at least two graves (chullpa I and III), all male individuals were kindred, possessing identical Y chromosome profiles. Relatedness coefficients indicate that those males were rather distant relatives and probably belonged to different generations. These data suggest that the community from Tompullo 2 site was composed of patrilineal family groups and members of each family group were buried in one grave.

Theoretical considerations of Andean kinship are most often based on the Juan Pérez Bocanegra diagram of Inca Kinship [63]. Implications from this diagram on ayllu organization were depicted in details by Isbell [11]. The model assumes that a couple that will marry should not belong to one ayllu. The groom's family should offer his sister to marry the bride's brother (so-called sister exchange). In the Andean communities, kin relation was recognized to the fourth level of kinship (third cousins) and marriages between relatives closer than third cousins were prohibited. These conditions result in a kinship scheme (Fig. 7.19 in [11]) that involves marriages between four distinct groups (families) in four generation cycles. Identification of such model from archaeological record is usually impossible; however, Isbell [11] describes chullpas from Chota-Cutervo region that show architectonic features and internal organization reflecting the ideal ayllu model.

In the case of Tompullo 2, detailed reconstruction of genealogical trees of each family or group was impossible due to the small sample size, but we believe that the observed pattern of burial could be a result of social organization similar to that presented by Isbell. Members of each group were buried in distinct chullpas that served as family graves, while the relationship shown between individuals found in different chullpas were an effect of marriages between members of distinct groups, resulting in the inclusion of the bride into the grooms family and finally in her burial in the husband's family grave.

This scenario is, however, altered by the results from chullpa VII where, from 4 male individuals, 3 different $\mathrm{Y}$ chromosome lineages were found. Individuals T2CH719 and T2CH730 possess an identical Y-STR profile. Individual T2CH729 carries a different Y chromosome, but has the same mtDNA as individual T2CH719 and R coefficients $\left(R_{Q G}=0.76\right.$ and $\left.R_{L R}=0.43\right)$ indicates that they were close relatives. Most probably they were sons of one mother and different fathers. This is not a case of individual T2CH715, autosomal microsatellites analysis indicates its close relationship to individual T2CH73 (female) buried in the same chullpa $\left(\mathrm{R}_{\mathrm{QG}}=0.64\right.$ and $\left.\mathrm{R}_{\mathrm{LR}}=0.26\right)$. They yielded different mtDNA haplotype and thus the only possible relationship explaining their high relatedness coefficient is that they share one father and two different mothers.

There is no evidence that chullpa VII somehow differs architecturally or archaeologically from the other chullpas found at Tompullo 2 [16]. Thus, there is no proof that this grave was used by a group any different from other inhabitants of this site. However, as it is stated by Isbell [11], the rules governing marriages and social organization were an idealization, and we cannot exclude a situation that was intentionally or unintentionally violated in some situations.

\section{Conclusions}

Genetic analyses of kinship relationships between individuals buried on the Tompullo 2 archaeological site reveal that individuals buried in the same chullpa were more closely related than those buried in different chullpas; moreover, all males buried in one chullpa share identical Y chromosome profiles (except for chullpa VII). These leads to the conclusion that this community was organized into patrilineal family groups. The use of chullpas as family graves is consistent with the idea of ayllu-based communities with kinship relationships as a foundation for each group. However, open sepulchers or chullpas were widely distributed in the Central Andes during the Late Horizon and many different types of such mortuary constructions could be found on sites with different ethnoarchaeological backgrounds [11]. Thus we cannot be sure that the model of social organization inferred in the Tompullo 2 site was universal for all Andean communities.

\section{Additional files}

Additional file 1: Full list of samples from Tompullo 2

archaeological site.

Additional file 2: Results of cloning of PCR products.

Additional file 3: Details of $Y$ chromosome STR multiplexes design and validation.

Additional file 4: Matrix of genetic distances $\left(F_{S T}\right)$ between Tompullo 2 and modern South American populations.

Additional file 5: Matrix of relatedness coefficients $\left(R_{Q G}\right.$ and $\left.R_{L R}\right)$ estimated for individuals from Tompullo 2 site.

\section{Authors' contribution}

$M B, A S, M S$ designed the study and collected the samples. MB performed the experiments and analyzed the data. KD developed and validated $Y$ chromosome multiplexes. MB, MS and PW wrote the manuscript. All authors read and approved the final manuscript.

\section{Acknowledgments}

We want to thanks Mariusz Ziolkowski from Center for Precolumbian Studies for help in organizing the study and sample collection. Our thanks are also to K. Pajak and M. Molak for their help and constructive comments. This study was supported by NCN grant no. NN303322234 directed by Anna Stanković and with the support of the project financing agreements POIG.02.02.00-14-024/08-00.

\section{Author details}

${ }^{1}$ Center for Precolumbian Studies, University of Warsaw, Krakowskie Przedmieście 26/28, 00-927, Warsaw, Poland. ${ }^{2}$ Institute of Genetics and 
Biotechnology, Department of Biology, University of Warsaw, Pawińskiego 5A, 02-106, Warsaw, Poland. ${ }^{3}$ Institute of Biochemistry and Biophysics, Polish Academy of Science, Pawińskiego 5A, 02-106, Warsaw, Poland. ${ }^{4}$ Centre of New Technologies, University of Warsaw, Miecznikowa 1, 02-096, Warsaw, Poland.

Received: 6 September 2011 Accepted: 27 March 2012

Published: 23 April 2012

\section{References}

1. Lalueza C: Lack of founding Amerindian mitochondrial DNA lineages in extinct aborigines from Tierra del Fuego-Patagonia. Hum Mol Genet 1997, 6:41-46.

2. Kemp BM, Tung TA, Summar ML: Genetic continuity after the collapse of the Wari empire: mitochondrial DNA profiles from Wari and post-Wari populations in the ancient Andes. Am J Phys Anthropol 2009, 140:80-91.

3. Lewis Jr, CM: Difficulties in rejecting a local ancestry with mtDNA Haplogroup data in the South Central Andes. Latin American antiquity 2009, 20(1):76-90.

4. Moraga M, Santoro CM, Standen VG, Carvallo P, Rothhammer F: Microevolution in prehistoric Andean populations: chronologic mtDNA variation in the desert valleys of northern Chile. Am J Phys Anthropol 2005, 127:170-181

5. Fehren-Schmitz L, Reindel M, Cagigao ET, Hummel S, Herrmann B. Pre-Columbian population dynamics in coastal southern Peru: A diachronic investigation of mtDNA patterns in the Palpa region by ancient DNA analysis. Am J Phys Anthropol 2010, 141:208-221.

6. Fehren-Schmitz L, Warnberg O, Reindel M, et al: Diachronic investigations of mitochondrial and Y-chromosomal genetic markers in pre-Columbian Andean highlanders from South Peru. Ann Hum Genet 2011, 75:266-283.

7. Keyser-Tracqui C: Nuclear and mitochondrial DNA analysis of a 2,000year-old necropolis in the Egyin Gol Valley of Mongolia. Am J Hum Genet 2003, 73(2):247-260.

8. Haak W, Brandt G: Ancient DNA, Strontium isotopes, and osteological analyses shed light on social and kinship organization of the Later Stone Age. Proc Natl Acad Sci U S A 2008, 105(47):18226-18231.

9. Zuidema R: The Inca kinship system: A new theoretical view. In Andean Kinship and Marriage, Special Publication No. 7. Edited by Bolton R, Mayer E Washington, DC: American Anthropological Association; 1977:240-281.

10. Klein H: Haciendas and ayllus: rural society in the Bolivian Andes in the eighteenth and nineteenth centuries. Standford: Stanford University Press; 1993.

11. Isbell W: Mummies and mortuary monuments: a postprocessual prehistory of Central Andean social organization. Austin: University Texas Press; 1997.

12. Osborne H: Indians of the Andes: Aymaras and Quechuas. London: Routledge; 2004

13. Salomon F: The Beautiful Grandparents: Andean Ancestors Shrines and Mortuary Ritual as Seen Trough Colonial Records. In Tombs for the Living: Andean Mortuary Practices. Edited by Tom D. Washington, D.C.: Dumbarton Oaks; 1995:315-353.

14. Dulanto J: The archaeological study of ancestor cult practices: The case of Pampa Chica, a Late Initial Period and Early Horizon site on the central coast of Peru. in: The Space and Place of Death. Edited by Silverman H. and Small DB. Archaeological Papers of the American Anthropological Association, 2002 11:97-117.

15. Flores Ochoa J, Prado JN del, Castillo M: Q'ero, el último ayllu Inka. Centro de Estudios Andinos, Cuzco 1984

16. Pawel Buda: Los sitios de Tompullo 1 y Tompullo 2 a la luz de los trabajos arqueológicos del proyecto "Condesuyos". In Andes: Boletín de la Misión Arqueológica Andina. Edited by Ziolkowski M, Belan Franco LA, Sobczyk M Warsaw: University of Warsaw; 2005:239-275.

17. Sobczyk M: Arquitectura funeraria prehispánica en la región del Nevado Coropuna, Perú. Warsaw: University of Warsaw; 2000.

18. Kolman CJ, Bermingham E, Cooke R, et al: Reduced mtDNA diversity in the Ngobe Amerinds of Panama. Genetics 1995, 140:275-283.

19. Kolman CJ, Bermingham E: Mitochondrial and nuclear DNA diversity in the Choco and Chibcha Amerinds of Panama. Genetics 1997, 147: 1289-1302.

20. Melton PE, Bricen I: Biological Relationship Between Central and South American Chibchan Speaking Populations: Evidence From mtDNA. Am J Phys Anthropol 2007, 770:753-770.
21. Vona G, Falchi A, Moral P, Calò CM, Varesi L: Mitochondrial sequence variation in the Guahibo Amerindian population from Venezuela. Am J Phys Anthropol 2005, 127:361-369.

22. Rickards O, Martínez-Labarga C, Lum JK, De Stefano GF, Cann RL: MtDNA history of the Cayapa Amerinds of Ecuador: detection of additional founding lineages for the Native American populations. Am J Hum Genet 1999, 65:519-530.

23. Lewis CM Jr, Lizárraga $B$, Tito RY, et al: Mitochondrial DNA and the peopling of South America. Hum Biol 2007, 79:159-178.

24. Lewis CM, Tito RY, Lizárraga B, Stone AC: Land, language, and loci: mtDNA in Native Americans and the genetic history of Peru. Am J Phys Anthropol 2005, 127:351-360

25. Fuselli S, Tarazona-Santos E, Dupanloup I, et al: Mitochondrial DNA diversity in South America and the genetic history of Andean highlanders. Mol Biol Evol 2003, 20:1682-1691.

26. Bert F, Corella A, Gené M, Pérez-Pérez A, Turbón D: Mitochondrial DNA diversity in the Llanos de Moxos: Moxo, Movima and Yuracare Amerindian populations from Bolivia lowlands. Ann Hum Biol 2004, 31:9-28.

27. Ward R, Salzano F, Bonatto S, et al: Mitochondrial DNA polymorphism in three Brazilian Indian tribes. Am J Hum Biol 1996, 8:317-323.

28. Schmitt $R$, Bonatto $S$, Freitas $L$, et al: Short Report Extremely limited mitochondrial DNA variability among the Aché Natives of Paraguay. Ann Hum Biol 2004, 31:87-94.

29. Moraga M, Rocco P, Miquel J, et al: Mitochondrial DNA polymorphisms in Chilean aboriginal populations: implications for the peopling of the southern cone of the continent. Am J Phys Anthropol 2000, 113:19-29.

30. Pruvost M, Schwarz R, Correia VB, Champlot S, Braguier S, Morel N, Fernandez-Jalvo Y, Grange T, Geigl EM: Freshly excavated fossil bones are best for amplifcation of ancient DNA. Proccedings of the National Academy of Science USA 2007, 104(3):739-744

31. Maniatis T, Fritsch EF, Sambrook J: Molecular cloning: a laboratory manual. Cold Spring Harbor Laboratory, Cold Spring Harbor, NY; 1989, 545.

32. Santos FR: Pandya a. Tyler-Smith C: Reliability of DNA-based sex tests. Nature genetics 1998, 18:103.

33. Sullivan K, Mannucci A: A rapid and quantitative DNA sex test: fluorescence-based PCR analysis of XY homologous gene amelogenin. Biotechniques 1993, 15(1):636-641.

34. Butler J, Shen Y, McCord B: The development of reduced size STR amplicons as tools for analysis of degraded DNA. Journal of Forensic Sciences 2003, 48(5):1054-1064

35. Drábek J, Chung D: Concordance study between Miniplex assays and a commercial STR typing kit. Journal of Forensic Sciences 2004, 49(4):859-860.

36. Chung D, Drábek J, Opel K: A study on the effects of degradation and template concentration on the amplification efficiency of the STR Miniplex primer sets. Journal of Forensic Sciences 2004, 49(4):733-740.

37. Reynolds J: Estimation of the coancestry coefficient: basis for a shortterm genetic distance. Genetics 1983, 105(3):767-779.

38. Excoffier L: Arlequin (version 3.0): an integrated software package for population genetics data analysis. Evol Bioinformatics Online 2005, 1:47-50.

39. Jobling MA, Gill P: Encoded Evidence: DNA in forensic analysis. Nat Rev Genet 2004, 5(10):739-751.

40. Just RS, Irwin JA, O'Callaghan JE, Saunier JL, Coble MD, Vallone PM, Butler JM, Barrit SM, Parson TJ: Toward increased utility of mtDNA in forensic identifications. Forensic Science International 2004, 146:SuppIS147-SuppIS149.

41. Holland MM, Parsons TJ: Mitochondrial DNA sequence analysis validation and use for forensic casework. Forensic Science Reviews 1999 11:21-50.

42. Butler J: Forensic DNA typing: biology, technology, and genetics of STR markers. 3rd edition. New York: Elsevier; 2005.

43. Queller DC, Goodnight KF: Estimating relatedness using molecular markers. Evolution 1989, 43:258-275.

44. Goodnight KF, Queller DC: Relatedness v. 5.0.8. Goodnight Software, Huston, 2001.

45. Lynch M, Ritland K: Estimation of Pairwise Relatedness With Molecular Markers. Genetics 1999, 152:1753-1766.

46. Peakal R, Smouse PE: GENALEX 6: genetic analysis in Excel. Population genetic software for teaching and research. Molecular Ecology Notes 2006, 6(1):288-295.

47. Csilléry $K$, Johnson $T$, Beraldi $D$, et al: Performance of marker-based relatedness estimators in natural populations of outbred vertebrates. Genetics 2006, 173:2091-2101. 
48. Wang J: An estimator for pairwise relatedness using molecular markers. Genetics 2002, 160:1203-1215.

49. Achilli A, Perego UA, Bravi CM, et al: The Phylogeny of the Four Pan-American MtDNA Haplogroups: Implications for Evolutionary and Disease Studies. PLoS One 2008, 3(3):e1764.

50. Tamm E, Kivisild T, Reidla M, Metspalu M, Smith DG, et al: Beringian standstill and spread of Native American founders. PLoS One 2007, 2(9):e829.

51. Pfeiffer H, Brinkmann B, Hühne J: Expanding the forensic German mitochondrial DNA control region database: genetic diversity as a function of sample size and microgeography. International Journal of Legal Medicine 1999, 112(5):291-298.

52. Wang S, Lewis CM Jr, Jakobsson M, et al: Genetic variation and population structure in Native Americans. PLoS Genetics 2007, 3:e185

53. Albeza M, Picornell A, Acreche N, et al: Genetic Variability at 14 STR loci in the Puna population of north western Argentina. International Journal of Legal Medicine 2002, 116:126-132.

54. Carnese FR, Mendisco F, Keyser C, et al: Paleogenetical study of preColumbian samples from Pampa Grande (Salta, Argentina). Am J Phys Anthropol 2010, 141:452-462.

55. Cooper A, Poinar HN: Ancient DNA: do it right or not at all. Science 2000, 289:1139-1139.

56. Poinar HN: The top 10 list: criteria of authenticity for DNA from ancient and forensic samples. Int Congr Ser 2003, 1239:575-579.

57. Kemp BM, Smith DG: Ancient DNA Methodology: "Thoughts from Brian M. Kemp and David Glenn Smith on "Mitochondrial DNA of Protohistoric Remains of an Arikara Population from South Dakota". Hum Biol 2010, 82:227-238.

58. Gilbert MTP, Bandelt H-J, Hofreiter M, Barnes I: Assessing ancient DNA studies. Trends in Ecology and Evolution 2005, 20:541-544.

59. Bandelt $\mathrm{H}$ : Mosaics of ancient mitochondrial DNA: positive indicators of nonauthenticity. Eur J Hum Genet 2005, 13(10):1106-1112.

60. Rodriguez-Delfin L, Rubin-de-Celis VE, Zago M: Genetic diversity in an Andean population from Peru and regional migration patterns of Amerindians in South America: data from Y chromosome and mitochondrial DNA. Hum Hered 2001, 51:97-106.

61. Tarazona-Santos E, Carvalho-Silva DR, Pettener D, et al: Genetic differentiation in South Amerindians is related to environmental and cultural diversity: evidence from the Y chromosome. Am J Hum Genet 2001, 68:1485-1496.

62. Smith CT: Depopulation of the Central Andes in the 16th Century. Curr Anthropol 1970, 11:453-464.

63. Bocanegra PJ: Ritual formulario; e institucion de Cura, para administrar a los naturales de este Reyno, etc. Lima, 1631

doi:10.1186/1471-2156-13-30

Cite this article as: Baca et al.: Ancient DNA reveals kinship burial patterns of a pre-Columbian Andean community. BMC Genetics 2012 13:30

\section{Submit your next manuscript to BioMed Central and take full advantage of:}

- Convenient online submission

- Thorough peer review

- No space constraints or color figure charges

- Immediate publication on acceptance

- Inclusion in PubMed, CAS, Scopus and Google Scholar

- Research which is freely available for redistribution 